\title{
ECONOMIC ANALYSIS FOR SIZING OF SUGARCANE (Saccharum spp.) MECHANIZED HARVESTING
}

\author{
NEISVALDO B. DOS SANTOS ${ }^{1}$, ROUVERSON P. DA SILVA², \\ CASIMIRO D. GADANHA JUNIOR ${ }^{3}$
}

\begin{abstract}
Sugarcane has a significant role on Brazilian agribusiness economy. The harvesting cane is considered as one of the most important operations of the process for it has to attend the raw material demanded by the sugar mill in quality and a competitive cost. The objective of this work it is it of analyzing, of systemic way, the variables influence on economical and operational performance in sugarcane mechanized harvesting process for sizing of machines. For this purpose a model called "ColheCana", was developed in a spreadsheet and in a programming language. The results showed that the field efficiency and harvester's initial value are variables of great impact in the cost and that there is a maximum area that one equipment can attend and for this area the cost is minimum.
\end{abstract}

KEYWORDS: agricultural mechanization, sugarcane harvester, computational model.

\section{ANÁLISE ECONÔMICA PARA O DIMENSIONAMENTO DA COLHEITA MECANIZADA DE CANA-DE-AÇÚCAR (Saccharum spp.)}

RESUMO: A cultura da cana-de-açúcar tem significativa participação na economia do agronegócio brasileiro. A colheita de cana é considerada como uma das operações mais importantes, pois deve atender à demanda de matéria-prima requerida pela Usina com qualidade e custo competitivo. $\mathrm{O}$ objetivo deste trabalho foi analisar, de modo sistêmico, a influência das variáveis no desempenho operacional e econômico do processo de colheita mecanizada da cana-de-açúcar para o dimensionamento das máquinas. Para tanto, foi desenvolvido um modelo, denominado de "ColheCana", em planilha eletrônica e em linguagem de programação. Os resultados evidenciaram que a eficiência de campo e o valor inicial das colhedoras são variáveis de grande impacto no custo e que existe uma área máxima a que um equipamento pode atender para a qual o custo é mínimo.

PALAVRAS-CHAVE: mecanização agrícola, colhedora de cana, modelo computacional.

\section{INTRODUCTION}

Brazil is the largest producer of sugarcane, culture destined to sugarcane sector, which occupies an estimated area of 8.44 million hectares, with planned total production of 641.98 million tons to be industrialized for the 2011-2012 harvest CONAB (2011).

The system of mechanized harvesting of sugarcane is considered as the most important in the production process due to the costs involved in the operation and influence the quality of raw material. To harvest all production of mechanized harvest, one must plan and scale the harvesting system, considering the factors of cost of machinery. BUCKMASTER (2003) in order to select best agricultural tractors noted that the fuel has a strong influence on the total cost of machinery. BANCHI et al. (2008a) to evaluate costs in sugarcane harvester concluded that $30 \%$ refers to fuel consumption and $33 \%$ with repair and maintenance.

\footnotetext{
${ }^{1}$ Mestre em Máquinas Agrícolas - ESALQ/USP, Prof ${ }^{\mathrm{o}}$ Assistente de Mecânica e Mecanização Agrícola - Campus Prof ${ }^{\mathrm{a}}$ Cinobelina Elvas (Bom Jesus-PI) - UFPI, neisvaldo@gmail.com

${ }^{2}$ Eng Agrícola, Prof. Adunto III, Departamento de Engenharia Rural, UNESP/Jaboticabal, Via de Acesso Prof. Paulo Donato Castellane, km 5, Jaboticabal - SP, rouverson@ fcav.unesp.br. Bolsista de Produtividade em Pesquisa - CNPq.

${ }^{3}$ Dr. em Energia na Agricultura pela Faculdade de Ciências Agronômicas, Prof. Dr. Escola Superior de Agricultura Luiz de Queiroz, cdgadanh@usp.br 
In mechanized harvesting of sugarcane system, as in any agricultural mechanized system, the cost factor is linked to the performance of the machines, as shown BAIO et al. (2013) who developed a linear model for evaluating agricultural mechanized systems in order to select the model system for lower operating cost. According to MAGALHÃES et al. (2008) the agricultural sector seeks increasingly to higher efficiency equipment and technology in order to increase the operational capacity, improve the efficiency of field machinery and provides lower loss and higher quality of sugarcane harvested in order to maximize profitability of agribusiness. Even the loss of raw materials has been an obstacle for the cost of harvesting in the Mill, even though according to SILVA et al. (2008) the loss of sugarcane in mechanized harvesting is under statistical quality control.

According to HANSEN et al. (2002) mechanized harvesting, should be planned in order to preserve the quality and the constant flow of raw materials to meet the demand of the Mill. According to COUTO et al. (2012) it is fundamental planning the design of agricultural operations not to overstate or even overload the machinery.

For BAIO et al. (2004) selection of machinery and implements is a difficult task because the choice of the most suitable equipment for the agricultural enterprise is regarded as one of the most important steps in the production process, since the rational selection of machines is difficult to perform because of the number of variables and options to consider.

Within this context the study aimed to exam, in a systemic way, the influence of operating variables and economic performance of the process of mechanical harvesting of sugarcane for the dimensioning of the machines.

\section{MATERIAL AND METHODS}

The beginning was considered a Basic Scenario for a Mill, here called Mill Standard (MS), with its own area of $22,000 \mathrm{ha}$, average yield of $80 \mathrm{Mg} \mathrm{ha}^{-1}$ and row spacing cultivation of $1.5 \mathrm{~m}$. Harvesting operations toggled to a double spacing between rows of $2.5 \mathrm{~m}$ in the same operation speed of the Base Scenario $\left(5 \mathrm{~km} \mathrm{~h}^{-1}\right)$ and $4 \mathrm{~km} \mathrm{~h}^{-1}$ has also been proposed. The spacing of the alternating double type is formed by two rows adjacent to each other. The crop was harvested by a combine harvester of a line, with $251 \mathrm{~kW}(342 \mathrm{cv})$ rated power of the engine and estimated initial value of $\mathrm{R} \$ 900,000.00$.

For harvesting operation occurs, losses of sugarcane was determined, ranging from 0 to $8.40 \%$, according to operating speed. The harvest in double spacing was considered a harvester of two lines being $30 \%$ higher initial estimated value relative to one line. Transship of raw material was carried by two trucks with capacity of $13 \mathrm{Mg}$, with an initial value of $\mathrm{R} \$ 50,000.00$ each, tensioned by a tractor $4 \times 2$ TDA $162 \mathrm{~kW}(220 \mathrm{cv})$ rated power of the engine, with initial value of $\mathrm{R} \$$ $160,000.00$.

To meet the objective of this work a computational model called "ColheCana" was developed to enables the inclusion of the basic features of the production for sugarcane system. The base model is the flow diagram in Figure 1, designed according to the characters proposed by OAKLAND (2007).

The "ColheCana" was developed in an electronic spreadsheet, Excel ${ }^{\circledR}$ and the programming language by Visual Basic ${ }^{\circledR}$. The model begins $(1)^{4}$ with the input data to the administrative area and climate (2): total number of days of harvest, number of sundays and holidays, the number of working days provided improper; workday; managerial efficiency (Me). The Me refers to the lost of time due to administrative problems, such as lack of trucks, lack of work order, stops unanticipated, among others. Further it holds input data for the characteristic of the culture (3) area, spacing average and productivity of crops. Based on these data, determine the operational tempo of the harvest (4).

\footnotetext{
${ }^{4}$ The numbers between parentheses refer to the flowchart of the Figure 1.
} 


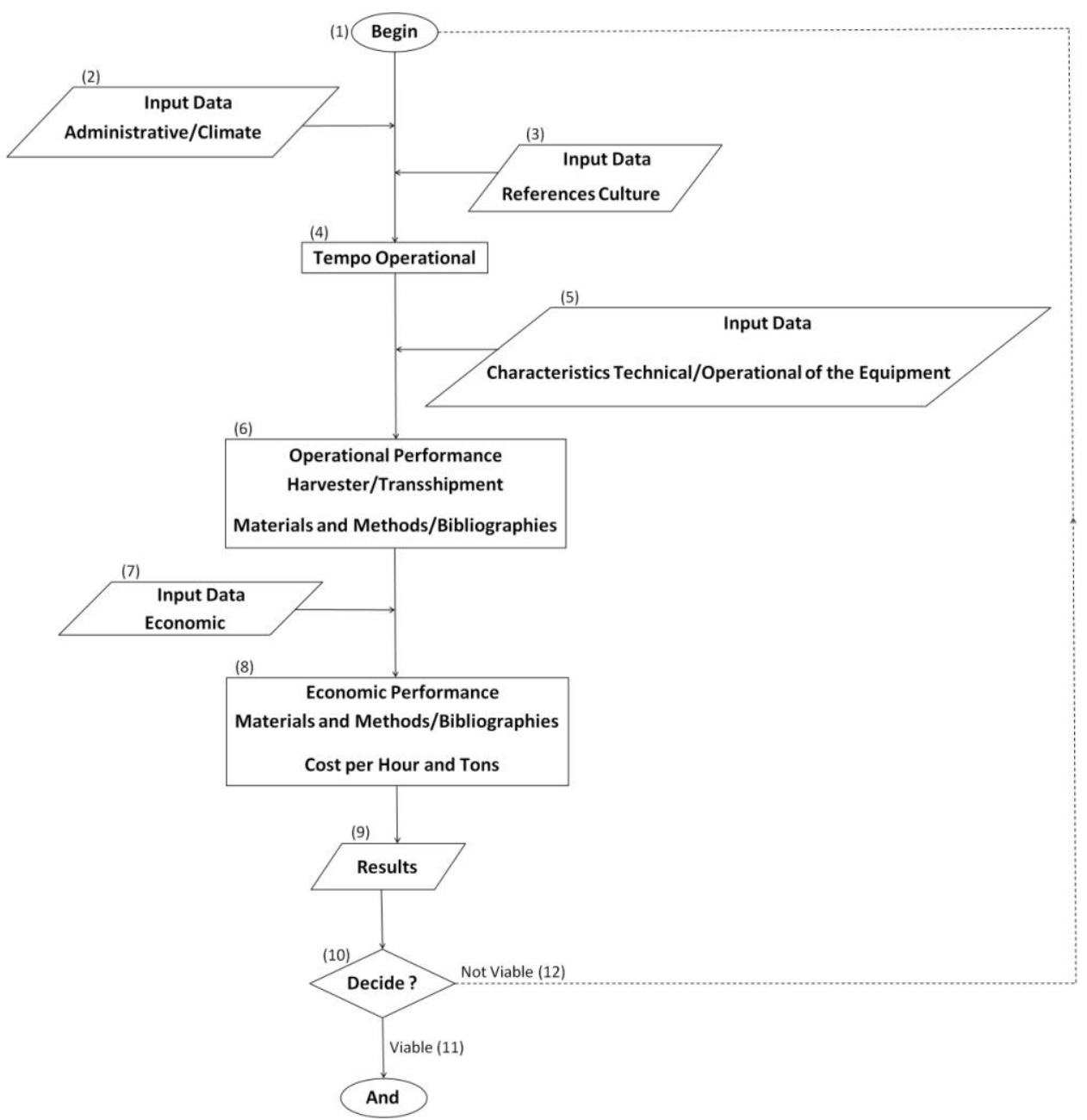

FIGURE 1. General flowchart of the computational model.

Then it holds the input data on the technical / operational characteristics of the equipment (5) used in crop: engine power, number of lines, working speed, crop losses, and efficiency of the field, among other. These data associated with the administrative data / climate, the operational tempo; determine the operating performance of the harvester / transshipment (6): field capacity (effective and operational) and production; fuel consumption, total distance, amount of cane harvested, number of harvesters and transshipments.

The results relating to operating performance, associated with the data entry of the economic portion (7) enables the calculation of the economic performance of the harvesting system (8): cost per hour, area and tons; fixed and variable costs, cost of losses in cane harvested. The input data of the economic part refer to: initial and final value; equipment lifetime, repair and maintenance; accommodation, insurance and fees factors, fuel price. The model results (9) allow the user to analyze the operational and economic performance of mechanized harvesting and decide (10) on the viability (11) or not of the same. In the case of the harvesting system does not meet the user's needs (12), or want to evaluate another scenario, new data should be entered for a next selection.

\section{Operational performance}

The operational and production performance of the harvester and transshipment ${ }^{5}$ was based on proposals by LOPES et al. (1995); MERCANTE et al. (2010); MIALHE (1974); MILAN (2004) and RIPOLI \& RIPOLI (2009). These proposals were used to define the number of equipment (harvesters, tractors and wagons) needed to meet a given sugarcane demand by the Mill.

\footnotetext{
${ }^{5}$ In this work the denomination transshipment is used to define the set of tractor and wagon(s).
} 
The number of harvesters was calculated according to the [eq. (1)].

$$
\mathrm{NH}=\frac{\mathrm{OR}}{\mathrm{OFC}}
$$

where,

$N H:$ number of harvesters;

$O R$ : operating rate $\left(\mathrm{ha}^{-1}\right)$, and

$O F C$ : operational field capacity of the harvester $\left(\mathrm{ha}^{-1}\right)$.

The operational rate (OR) was calculated by the ratio between the area to be harvested (AHh) and the time available (TA).

The calculation of time available (TA) was obtained by adding the number of sundays and holidays (Nsh) and the number of days unfit (Ndu) then deducted them from the total number of days (Tnd) and the values linking to workday (Lw) and managerial efficiency (Me).

The operational field capacity (OFC) was calculated according to the association's line number (s) of the harvester (LNH), spacing of crops (SC), operating speed (OS) and the efficiency of field (Ef).

Based on performance in field operations (OFC) and average crop yield (ACY), can calculate the operational production capacity of the harvester (OPC).

The total loss of sugarcane (TLS) (\%) is calculated as a function of the operating speed of the harvester (OS), according to proposed by RIPOLI (1996).

\section{Transshipment number}

Transshipment performs internal transport, removing the harvested cane by harvester depositing it in the transport vehicle (logistics). The number of transfers (NT) required to meet a harvester is shown in [eq. (2)].

$$
\mathrm{NT}=\frac{\mathrm{OPC}}{\mathrm{OTCt}}
$$

where,

$N T$ : number of transfers to meet a harvester, and

OTCt: operating transport capacity of the transshipment $\left(\mathrm{Mg} \mathrm{h}^{-1}\right)$.

The operational capability of transporting transshipment (OTCt) was determined by the ratio between the total capacity of the transshipment (TCTt), the total time of the loading cycle (TT) and the association with the efficiency of cycle of transshipment (Efct).

The total loading time (TT) cycle was calculated by the sum of the loading time of transshipment (TLg), discharge time of transshipment (DTt) and travel time of transshipment (TTT).

The load time of transshipment (TLg) was calculated by the association of load capacity of a car body (LCcb) with the number of car bodies that make up the transshipment (NCbt) and the result of this association, due to operational production capacity of the harvester (OPC).

The time travel (TTT) corresponds to the time of transshipment route taken by displacement loaded way, harvester to the empty truck and return the truck to the harvester. The travel time was calculated as the ratio of the average distance between the harvester and transport vehicle (truck) (ADHTv) and the speed of the transshipment (ST). The speed of operation considered for the harvester and transshipment was $5.0 \mathrm{~km} \mathrm{~h}^{-1}$, with the same speed of travel from transshipment to the truck. 


\section{Economic performance}

The production operating cost of harvester (POCh) was determined by the ratio of the hourly cost of the harvester (HCh) and operational production capacity of the harvester (OPC).

The hourly cost of the harvester $(\mathrm{HCh})$ was calculated by the sum of the fixed cost per hour (FCH) and variable costs (VC).

The fixed cost per hour $(\mathrm{FCH})$ of the harvester was calculated based on the methodology proposed by ASABE (2011), which is defined by the ratio of the annual fixed cost (AFC) and number of hours worked per year (NHWy).

Variable cost (VC) of the harvester is the sum of expenses related to fuel, repair and maintenance of the machine.

To calculate the fuel consumption (FC) for the harvester two alternatives in the model are provided. The first based on the values proposed by BANCHI et al. (2008c) for three different consumption situations: min $\left(35.19 \mathrm{~L} \mathrm{~h}^{-1}\right)$, medium $\left(39.12 \mathrm{~L} \mathrm{~h}^{-1}\right)$ and maximum $\left(43.06 \mathrm{~L} \mathrm{~h}^{-1}\right)$. The second alternative refers to the use of the consumption model proposed by TACHIBANA \& MILAN (2002) for agricultural tractors, [eq. (3)]:

$$
\mathrm{FC}=\left\{\left[0.728(\mathrm{X})^{2}\right]-[1.2109(\mathrm{X})+0.8054]\right\} *\left[\left(\mathrm{E}_{\mathrm{p}}\right) 0.83\right]
$$

where,

$X$ : power ratio in decimal, and

Ep: engine power supplied by the manufacturer $(\mathrm{kW})$.

In the proposed equation, the power ratio $(\mathrm{X})$ refers to the ratio between the power required by the tractor take-off (PTO) and the maximum power of the take-off. For the present case was added a "factor" for the maximum engine power of the harvester (Ep). The multiplication of Pm by the factor 0.83 according to ASABE (2011) was done with the purpose of transforming Pm in an "equivalent power of take-off. In this case, the power ratio $(\mathrm{X})$ is defined by the load imposed by the harvester on the sugarcane plantation and the maximum equivalent power on the machine, adjusted by the factor 0.83 .

The cost of repair and maintenance (CRM) of the harvester was calculated according to ASABE (2011).

For the harvester, the factor of repair and maintenance (FRM) was used in accordance with the proposal of BANCHI et al. (2008b), [eq. (4)]. The empirical equation was developed based on a database of eight power plants for harvesters manufactured between 1997 and 2007.

$$
\mathrm{FRM}=4 \mathrm{E}^{-09 L \mathrm{Th}^{2}}+3 \mathrm{E}^{-05 \mathrm{LTh}}
$$

where,

LTh: lifetime in hours of the machine.

\section{Cost inland transport}

The cost of transshipment of raw material (CTRm) was calculated by the ratio of the time cost of transshipment (TCT) and the operational capacity of the transshipment transport (OTCt).

The time cost of transshipment (TCT) was calculated by the sum of the fixed cost per hour $(\mathrm{FCH})$ and variable costs (VC).

The fixed cost per hour (FCH) transshipment was calculated based on the methodology proposed by ASABE (2011), in the same way as that used to calculate the hourly cost of the harvester. 
The calculation of hours worked per year (NHWyt) of transshipment was the same as that used for the harvester. Regarding to the operational field capacity (OFC) of transshipment, the harvester was considerate.

Variable cost (VC) of the transshipment is the sum of expenses related to fuel, repair and maintenance of machinery. To calculate the fuel consumption of the tractor in transshipment, was considered the average values of consumption for power range of tractor engine, proposed by BANCHI et al. (2008c).

The calculation of the cost, repair and maintenance (CRM) and the repair and maintenance (FRM) factor of transshipment are according to ASABE (2011).

\section{Data Analysis}

Data analysis and validation of the "ColheCana" was performed by comparing the results obtained in the simulation, with primary (raw) and secondary (bibliography). Was evaluated the consistency of the model with respect to cost.

\section{RESULTS AND DISCUSSION}

According to the results obtained for the Base Scenario, mechanized harvesting (harvester) represents $75.51 \%$ of the costs, while the internal transport in the field, tractor and car bodies, representing 24.49\% (Figure 2a).
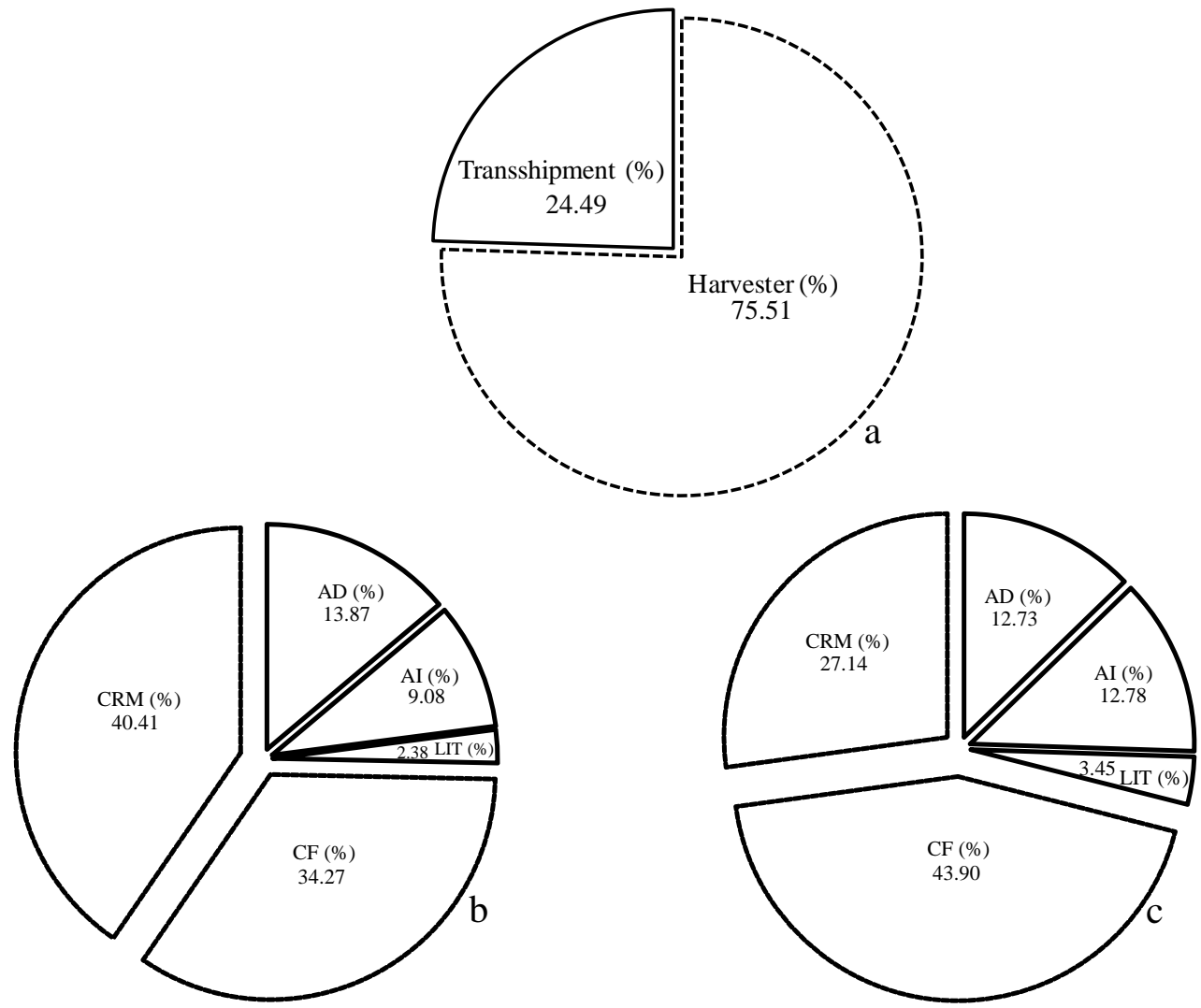

FIGURE 2. Distribution of costs (\%) for the Basic Scenario: a - Harvester and transshipment; $b$ Harvester; c - Transshipment. CRM - (Cost of repair and maintenance), CF - (Cost of fuel), AD - (Annual depreciation), AI - (Annual interest) and LIT - (Lodging, insurance and taxes).

For the harvester the variable with the highest expression in the cost refers to the repair and maintenance (CRM) with $40.41 \%$, followed by fuel (CF) with $34.27 \%$ totaling $74.68 \%$ (Figure 2b). 
These two items make up the variable cost and therefore the fixed cost represents $25.32 \%$. For the cost of transshipment the major variable in expression refers to the fuel (CF) with $43.90 \%$, followed by repair and maintenance $(\mathrm{CRM})$ with $27.14 \%$ totalizing $71.04 \%$ of variable costs and fixed costs of $28.96 \%$ (Figure $2 \mathrm{c}$ ).

For an area of 500 hectares the crop cost is $8.33 \mathrm{R} \$ \mathrm{Mg}^{-1}$, while the transshipment is $4.40 \mathrm{R} \$$ $\mathrm{Mg}^{-1}$ totaling $12.73 \mathrm{R} \$ \mathrm{Mg}^{-1}$ (Figure 3). As growth occurs in the surface area, the cost per ton decreases until it reaches the maximum possible area to be harvested, equivalent to 2,148 ha.

In the situation of maximum area (2,148 ha) the cost of harvesting is $4.65 \mathrm{R} \$ \mathrm{Mg}^{-1}$ and for transshipments $2.31 \mathrm{R} \$ \mathrm{Mg}^{-1}$, totaling $6.96 \mathrm{R} \$ \mathrm{Mg}^{-1}$. This decrease in cost is due to the dilution of fixed costs of equipment by hours worked. The larger the area, the greater the number of hours worked by the equipment until the situation in which operational capacity is not sufficient to meet the operational tempo within the prescribed period, which implies the entry of a new harvester and two transshipments.

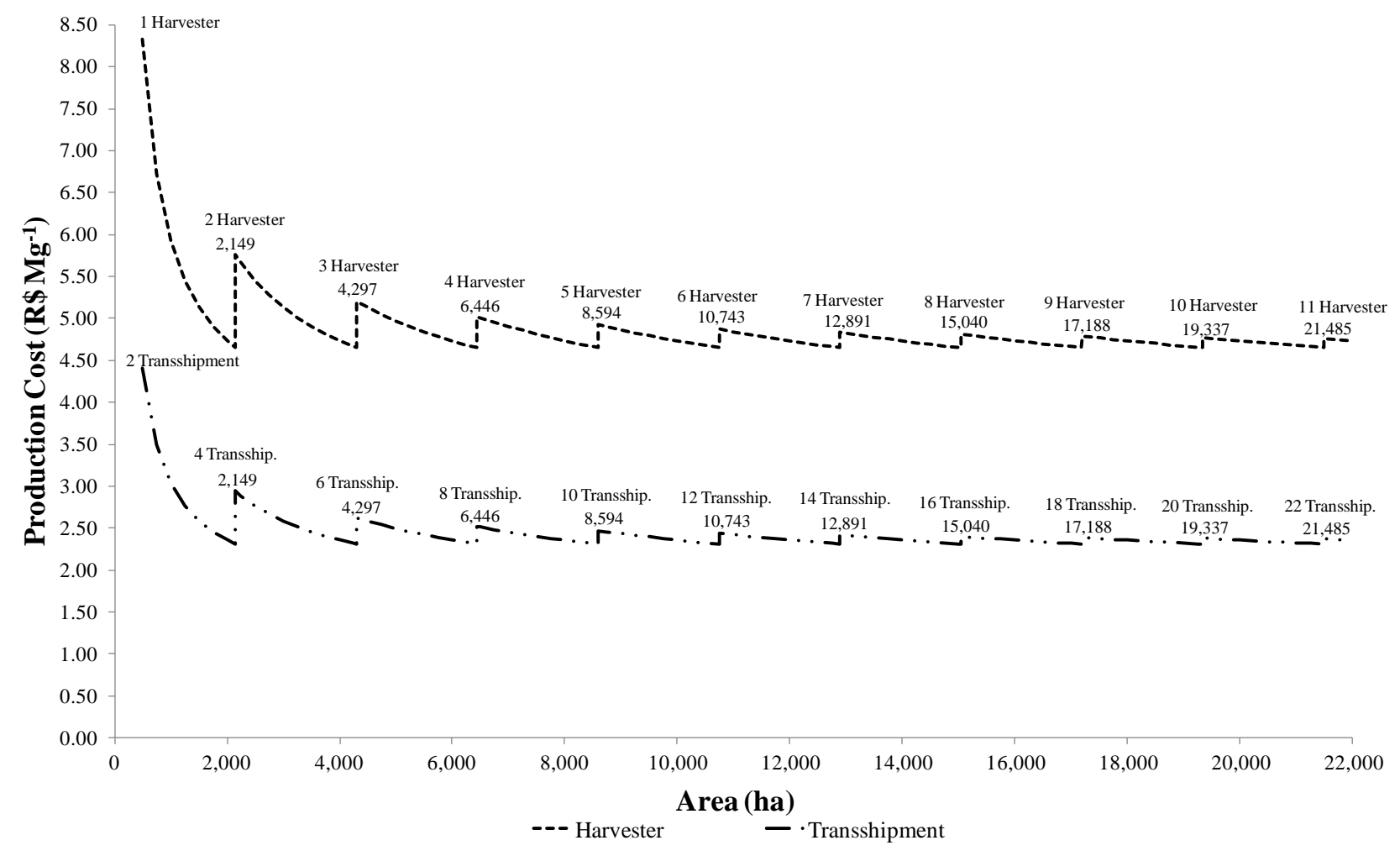

FIGURE 3. Production cost as a function of area for harvester and tractor-transshipment.

With $500 \mathrm{ha}$, the harvester operates $833 \mathrm{~h}$ and $520 \mathrm{~h}$ transshipment. To 2,148 ha each harvester operates $3,580 \mathrm{~h}$ and $2,198 \mathrm{~h}$ transshipment. With the entry of a new machine, which is 2,149 ha with each harvester must operate $1,791 \mathrm{~h}$ and 1,099 $\mathrm{h}$ transshipment totaling 3,582 $\mathrm{h}$ and $4,397 \mathrm{~h}$ of harvest for domestic transport. To meet the 22,000 ha of the Base Scenario it is necessary eleven harvester and forty four transshipment with the cost of $4.73 \mathrm{R} \$ \mathrm{Mg}^{-1}$ and $2.36 \mathrm{R} \mathrm{Mg}^{-1}$ respectively. One of the technological alternatives that the sugarcane sector has adopted is the change in cropping spacing from $1.5 \mathrm{~m}$ between single rows on Base Scenario, to double spacing alternated with planting spacing of $2.5 \mathrm{~m}$ between rows. The proposal is to obtain the same yield per unit area, but increasing the working capacity of the harvester as it passes the scoop two rows instead of one.

The harvester of two lines on the same operation speed of the Base Scenario $\left(5 \mathrm{~km} \mathrm{~h}^{-1}\right)$ becomes more economical from an area of 1,150 ha, while the speed of $4 \mathrm{~km} \mathrm{~h}^{-1}$ the cost is higher to 2,148 ha, such area needs a second harvester of one line (Figure 4). The exact need for a new 
harvester of a line occurs at 2,149 ha for Basic Scenario and for harvester of two lines at the speed of $4 \mathrm{~km} \mathrm{~h}^{-1}$ occurs at 2,865 ha, while for the two lines at the speed of Scenery Basic $\left(5 \mathrm{~km} \mathrm{~h}^{-1}\right)$ the purchase of a new machine from 3,581 ha will be needed.

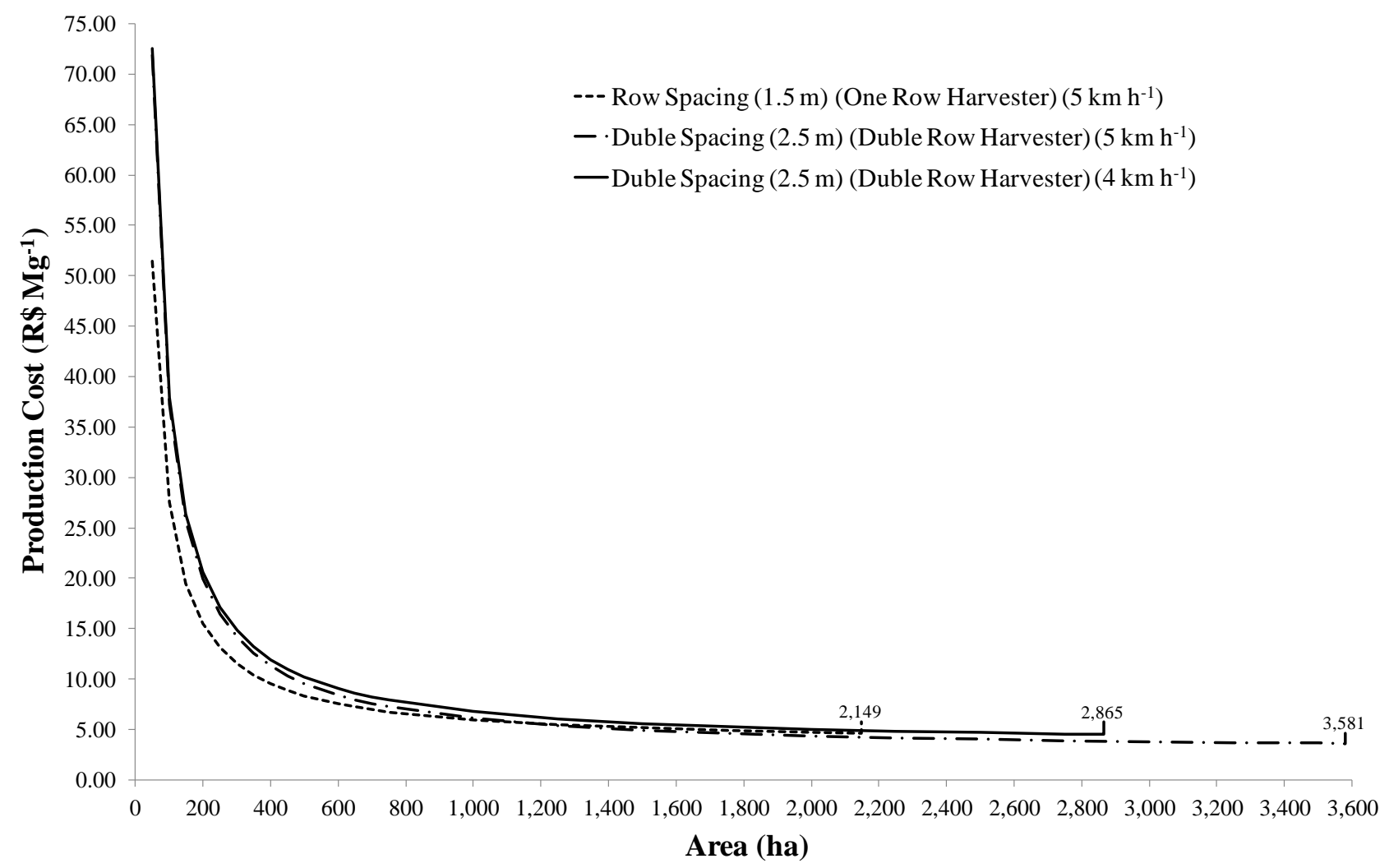

FIGURE 4. Cost of production to the area of cultivation in different spacing.

Considering the use of two lines harvester the original fleet of eleven harvesters to meet the Basic Scenario, can be reduced to eight harvesters of two lines on the same operating speed of the Base Scenario $\left(5 \mathrm{~km} \mathrm{~h}^{-1}\right)$. For 2,149 ha the cost per ton is $5.77 \mathrm{R}_{\mathrm{Mg}} \mathrm{Mg}^{-1}$ for one row harvester, while the 2,865 ha with two lines harvesters at the speed of $4 \mathrm{~km} \mathrm{~h}^{-1}$ the cost per ton is $5.71 \mathrm{R} \$ \mathrm{Mg}^{-1}$ and 4.56 R $\$ \mathrm{Mg}^{-1}$ to 3,581 ha for two lines harvester at the speed of the Base Scenario $\left(5 \mathrm{~km} \mathrm{~h}^{-1}\right)$. In this situation to harvest the 3,600 ha must be traversed 24,000 kilometers by a line and $14,400 \mathrm{~km}$ by two lines machine.

For low speed operation $1 \mathrm{~km} \mathrm{~h}^{-1}$, the cost reaches $34.80 \mathrm{R} \$ \mathrm{Mg}^{-1}$ and $34.51 \mathrm{R} \$ \mathrm{Mg}^{-1}$ for operating the harvester with and without loss, respectively (Figure 5). The two values are almost equal and losses at this rate equal $0.81 \%$. With increasing speed, the losses increase linearly but the cost decreases, due to increased operating capacity obtained. For a speed of $7 \mathrm{~km} \mathrm{~h}^{-1}$, expected losses represent $5.87 \%$ and the difference in operating costs with and without losses is $0.31 \mathrm{R} \mathrm{Mg}^{-}$ ${ }^{1}$. For the Baseline Scenario, the estimated harvest in the crop is $1,760,000 \mathrm{Mg}$ and value of losses represent $\mathrm{R} \$ 4,135,257.28$. 


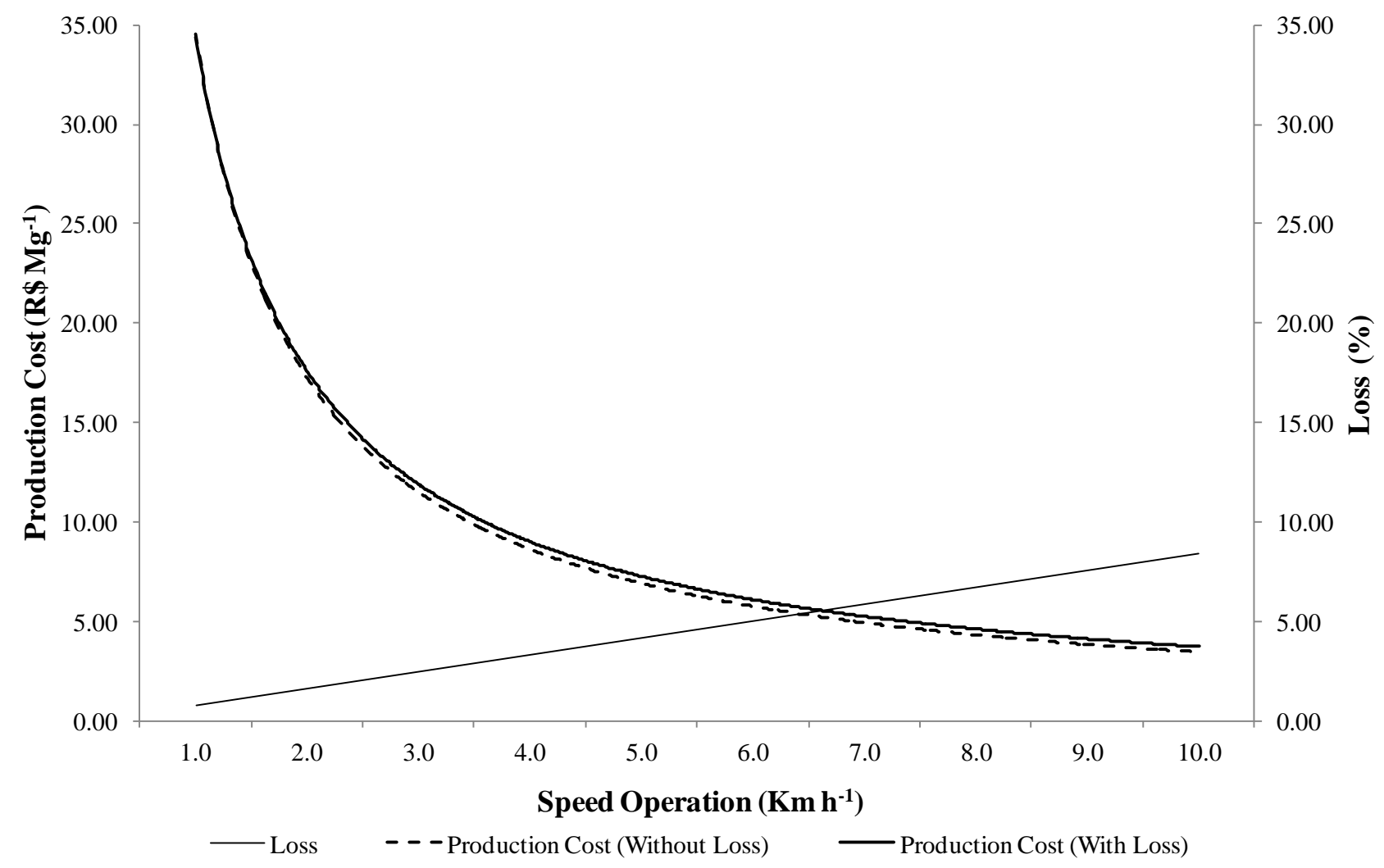

FIGURE 5. Production costs of the harvester and the total loss of sugarcane in terms of speed operation.

Given the absence of modeling work for the design of machines and cost evaluation of a mechanized harvesting system of sugarcane, this work aims to be a useful tool for taking management decision for a Mill.

\section{CONCLUSIONS}

In mechanized harvesting process, the harvester causes more impact in costs.

The change in spacing of the crop, reduces the number of machines and the traveled distance in the harvest.

The increase in speed of operation involves positively operating performance, but increases the loss of sugarcane and the production cost.

\section{REFERENCES}

ASABE. American Society of Agricultural and Biological Engineers. Agricultural machinery management data ASAE D497.7. ASABE Standards. St. Joseph, 2011. p. 1-8.

BAIO, F.H.R.; ANTUNIASSI, U.R.; BALASTREIRE, L.A.; CAIXETA FILHO, J.V. Modelo de programação linear para seleção de pulverizadores agrícolas de barras. Engenharia Agrícola, Jaboticabal, v. 24, n. 2, p. 355-363, 2004.

BAIO, F.H.R.; RODRIGUES, A.D.; SANTOS, G.S.; SILVA, S.P. Modelagem matemática para seleção de conjuntos mecanizados agrícolas pelo menor custo operacional. Engenharia Agrícola, Jaboticabal, v. 33, n. 2, p. 402-410, 2013.

BANCHI, A.D.; LOPES, J.R.; ZAGO, C.A. Estudo dos custos com reparo e manutenção em colhedoras de cana-de-açúcar parte I. Agrimotor, São Paulo, n. 30, p. 12-13, 2008a. 
BANCHI, A.D.; LOPES, J.R.; ZAGO, C.A. Estudo dos custos com reparo e manutenção em colhedoras de cana-de-açúcar parte II. Agrimotor, São Paulo, n. 31, p. 8-10, $2008 \mathrm{~b}$.

BANCHI, A.D.; LOPES, J.R.; ZAGO, C.A. Uso anual e consumo de combustível em frotas agrícolas. Agrimotor, São Paulo, n. 39, p. 8-10, 2008 c.

BUCKMASTER, D.R. Benchmarking tractor costs. Applied Engineering in Agriculture, St. Joseph, v. 19, n. 2, p. 151-154, 2003.

CONAB. Companhia Nacional de Abastecimento. Acompanhamento da safra brasileira: cana-deaçúcar, primeiro levantamento. Brasília, 2011.

COUTO, R.F.; CUNHA, J.P.B.; REIS, E.F. Modelo de programação linear para seleção de diferentes formas de pulverização agrícola para cana-de-açúcar. Engenharia na Agricultura, Viçosa, v. 20, n. 6, p. 529-536, 2012.

HANSEN, A.C.; BARNES, A.J.; LYNE, P.W.L. Simulation modeling of sugarcane harvest-to-mill delivery systems. Transactions of the ASAE, St. Joseph, v. 45, n. 3, p. 531-538, 2002.

LOPES, J.D.S.; MANTOVANI, E.C.; PINTO, F.A.C.; QUEIROZ, D.M. Desenvolvimento de um programa computacional para selecionar, economicamente, um sistema de mecanização agrícola. Pesquisa Agropecuária Brasileira, Brasília, v. 30, n. 4, p. 537-542, 1995.

MAGALHÃES, P.S.G.; BALDO, R.F.G.; CERRI, D.G.P. Sistema de sincronismo entre a colhedora de cana-de-açúcar e o veículo de transbordo. Engenharia Agrícola, Jaboticabal, v. 28, n. 2, p. 274282, 2008.

MERCANTE, E.; SOUZA, E.G.; JOHANN, J.A.; GABRIEL FILHO, A.; URIBE-OPAZO, M.A. Praprag - software para planejamento racional de máquinas agrícolas. Engenharia Agrícola, Jaboticabal, v. 30, n. 2, p. 322-333, 2010.

MIALHE, L.G. Manual de mecanização agrícola. São Paulo: Agronômica Ceres, 1974. 301 p.

MILAN, M. Gestão sistêmica e planejamento de máquinas agrícolas. 2004. $100 \mathrm{f}$. Tese (LivreDocência) - Escola Superior de Agricultura "Luiz de Queiroz”, Universidade de São Paulo, Piracicaba, 1994.

OAKLAND, J. Gerenciamento da qualidade total tqm. São Paulo: Nobel, 2007. 459 p.

RIPOLI, T.C.C. Ensaio \& certificação de máquinas para colheita de cana-de-açúcar. In: MIALHE, L.G. Máquinas agrícolas ensaios \& certificação. Piracicaba: FEALQ, 1996. cap. 13, p. 635-673.

RIPOLI, T.C.C.; RIPOLI, M.L.C. Biomassa de cana-de-açúcar: colheita, energia e ambiente. Piracicaba: Edição dos Autores, 2009. 333 p.

SILVA, R.P.; CORRÊA, C.F.; CORTEZ, J.W.; FURLANI, C.E.A. Controle estatístico aplicado ao processo de colheita mecanizada de cana-de-açúcar. Engenharia Agrícola, Jaboticabal, v. 28, n. 2, p. 292-304, 2008.

TACHIBANA, A.; MILAN, M. Modelo para avaliação de sistemas mecanizados para aplicação de defensivos em culturas perenes. Engenharia Agrícola, Jaboticabal, v. 22, n. 1, p. 101-109, 2002. 


\section{ERRATA}

No artigo "ECONOMIC ANALYSIS FOR SIZING OF SUGARCANE (Saccharum spp.) MECHANIZED HARVESTING” publicado na revista Engenharia Agrícola, no volume 34, número 5: páginas 945-954, na página 945, onde se lia:

Recebido pelo Conselho Editorial em:

Aprovado pelo Conselho Editorial em:

\section{Leia-se:}

Recebido pelo Conselho Editorial em: 21/05/2012 Aprovado pelo Conselho Editorial em: 03/12/2013 